\title{
Arts Based Education Relevance in Serat Wedhatama By K.G.P.A.A Mangkunegaran IV in Nusantara
}

\author{
Setyo Pambudi ${ }^{1 *}$, Sigit Tri Utomo ${ }^{2}$, Nur Alfi Muanayah ${ }^{3}$ \\ ${ }^{1}$ Islamic Religious Education Study Program, UIN Sunan Kalijaga Yogyakarta, Indonesia; ${ }^{2,3}$ STAINU \\ Temanggung, Central Java, Indonesia \\ *email: pambudis650@gmail.com
}

\begin{abstract}
This research is intended to find out the values of Islamic Education in the Wedhatama book written by KGPAA Mangkunegaran IV which is very relevant today. This research is a type of literature study research by looking for theoretical references that are relevant to the cases or problems found. Data collection techniques using documentation, observation and study literature Tajusalatin Fiber. The data that has been obtained are then analyzed using descriptive analysis methods. Descriptive analysis method is carried out by describing the facts which are then followed by analysis, not only describing, but also providing adequate understanding and explanation. To understand the full meaning of Wedhatama, it is necessary to begin with knowing the outline of the contents of the Pupuh tembang pangkur, which is an opening of the teachings that in general to walk towards "Penembah" must begin with "ngungkuraken angkara", which is to throw away the nature and attitude of the haunted, greedy, greed, wrath, cunning, envy, envy and so on. Character or virtue, as one of the basic teachings in religion, in order to be implemented in society, the king needs to be supported by all his apparatus. Meanwhile, a king who is aware of his mission and duty to uphold goodness, must need religious guidance, as seen in the expression "religion ageme aji".
\end{abstract}

Keywords:

Education; Art; Serat Wedhatama.

\begin{abstract}
ABSTRAK
Penelitian ini dimaksudkan untuk mengetahui nilai-nilai Pendidikan Islam dalam kitab Wedhatama karangan KGPAA Mangkunegaran IV yang sangat relevan di masa sekarang. Penelitian ini termasuk jenis penelitian studi literatur dengan mencari referensi teori yang relefan dengan kasus atau permasalahan yang ditemukan. Teknik pengumpu;an data menggunakan dokumentasi, observasi dan
\end{abstract}


study literature Serat Tajusalatin. Data-data yang sudah diperoleh kemudian dianalisis dengan metode analisis deskriptif. Metode analisis deskriptif dilakukan dengan cara mendeskripsikan fakta-fakta yang kemudian disusul dengan analisis, tidak semata-mata menguraikan, melainkan juga memberikan pemahaman dan penjelasan secukupnya. Untuk memahami keseluruhan makna hakiki Wedhatama, perlunya kiranya diawali dengan mengenal garis besar isi Pupuh tembang pangkur, merupakan pembuka ajaran yang pada garis besarnyauntuk berjalan menuju "Penembah" harus diawali dengan "ngungkuraken angkara", yakni membuang jauh-jauh sifat dan sikap angkara, loba, tamak, murka, culas, dengki, iri dan sebagainya. Budi pekerti atau budi luhur, sebagai salah satu ajaran dasar dalam agama, agar terlaksana dalam masyarakat, perlu didukung raja dengan segala aparatnya. Dalam pada itu seorang raja yang menyadari missi dan tugasnya untuk menegakan kabaikan, mesti membutuhkan pedoman agama, seperti terlihat dalam ungkapan " agama ageme aji”.

Kata Kunci:

Pendidikan; Seni; Serat Wedhatama.

\section{Introduction}

The Indonesian nation is a nation that is rich in cultural heritage, which is stored in regional culture throughout the archipelago, which is spread from Sabang to Merahoke. Cultural heritage is in the form of written and unwritten relics, such as petilasan, temples, and literary works of both fiction and non-fiction, all of which are very valuable cultural values possessed by the Indonesian people. Among the areas that are rich in culture and literature are the Javanese. In Java we find many written remains, in the form of texts containing Moral education (Akhlak), religious teachings, philosophy, and kasampurnan sciences. In Javanese literature we recognize the existence of suluk books, Wirid, Primbon, Menak, babad and others. Each name of the book has different contents and contents, as well as different teachings and all of them have their own uses or benefits according to the users' opinion.

Manuscripts, namely essays that are still written by hand (manuscripts) or the original writings of the authors themselves. Basically the cultural results of a nation cannot be separated from the influence of its time. This culture is an inseparable part of the linguistic system, because language is a vehicle for literature / cultural products and literature itself is often referred to as a mirror of society. taught (Damana, 1978: 1). The study of literary works can play a very significant role in science. This is due to examining the literary works created by the poets in revealing the cultural elements contained therein. As we can take the moral teachings (Akhlak) that are stored in it, because those teachings are able to become guidelines and guidelines for the people of their time, even at present and in the future (Darusuprapta, 1986: iii).

Wedhatama fibers contain noble teachings to build Javanese spiritual cultivation. Wedhatama fibers become one of the bases for universal spiritual practice across beliefs or religions. In wedhatama fibers contain the voice of conscience which becomes a spiritual practice to reach a life with a high spiritual level the peak of practice Spirituality in Serat Wedhatama is finding true life, better understanding oneself, and God's gift to see the unseen (Wibawa, 2013: 15). It is is only natural 
that observers or observers of the results of Javanese literature give the name that the results of literature, art and culture in the early Surakarta era were the period of Reneization or the era of spiritual beauty (Simuh, 1986: 9).

According to Kuntjara Ningrat, because of the strong influence between Hinduism, Buddhism and Islam. In its development, the Javanese religion has two features, namely Islam 1) Syncretism, which unites pre-Hindu and Islamic elements and 2) Islam that is puritan or which follows the religion more obediently (Koentjaraningrat 1985: 310). The progress of the current development of the era has a negative impact on Javanese society in particular and for the general public, where technological advances create a world without borders and it is easy to find the information needed, but this convenience is not matched by clear filters and causes misuse of information sources among adolescents. and resulted in juvenile delinquency. Apart from that, the loss of the original personality of the region or what is called a symptom of cultural erosion is also a factor in the failure to cultivate youth character.

Actually, Indonesia has a high and noble heritage of ancestral culture whose teachings are no less important than those of the West. One of them is Serat Wedhatama. Javanese people are familiar with religious teachings, subosito, the karma system of solidarity tall one. In order to spread Islam, the guardians first made adaptive steps to let Javanese culture take root strongly (prioritizing the spiritual aspect) with the insertion of doctrine through folk music or songs: Like Sunan Bonang preaching with gamelan, Sunan Giri with Gamelan and Sunan Kalijaga with Wayang, Sekaten, buildings Hindu style with Islam. Packaging deviant customs is politely corrected, not prohibiting but showing a good way, so that Islam can develop rapidly in Indonesia until now (Ibn Ismail 2010: 15).

\section{Method}

This research is a type of literature study research by looking for theoretical references that are relevant to the cases or problems found. (Nata, 2000: 125). The theoretical references obtained by means of literature study research serve as the basic foundation. The object of this research focuses on the values of Islamic education in Serat Wedhatama. Data collection techniques used documentation by reviewing documents related to Whedatama fibers, observations related to literature related to Whedatama fibers and literature review related to Whedatama fibers.. (Usman and Purnomo, 1996: 64). The data that has been obtained are then analyzed using descriptive analysis methods. Descriptive analysis method is carried out by describing the facts which are then followed by analysis, not only describing, but also providing sufficient understanding and explanation. (Subagyo, 1991: 106)

\section{Findings}

\section{Definition of Wedhatama Fiber}

Wedha Tama comes from the word Wedha which means science or teaching (Javanese: Kawruh), Tama means good or noble. So Serat (manuscripts) Wedha Tama is a teaching about noble mind. Serat Wedha Tama was written by Kanjeng Gusti Pangeran Adipati Arya Mangkunagara IV 
from Surakarta. The teachings contained in Serat Wedha Tama contain about character education in the wider community which is universal. Wedhatama fiber contains a very deep meaning which means: Fiber is a book, while Wedhatama means the main knowledge, Wedhatama fiber is one of the ancient Javanese books (piwulang and piweling books) which are very popular among Javanese people. In Serat Wedhatama there are piwulang and piweling sublime which contain the concepts of divinity, society and humanity. Wedhatama from the word "Wedha" means science and "Tama" means the main, "Wedhatama" the main knowledge. (Any 1986: 177).

Serat Wedhatama is a book of Javanese philosophy which contains noble teachings, so it is very good as a reading for the current generation. Wedhatama is formed from two words, namely Wedha and Tama.Wedha means knowledge and teachings, while Tama or Utama means good, noble, or high value (KGPAA Mangkunegara IV 1989: 115). The meaning of Wedha according to Prof. KawiIndonesian dictionary. Drs. Wojowasito is "science." While the word TAMA comes from the origin of the word UTAMA which means GOOD. So wedhatama means the science of goodness. It turns out that it is not only good knowledge about birth but also good for both physical and mental. Wedhatama which consists of 100 stanzas (stanzas) tembang and consists of 5 songs: Pangkur, Sinom, Pucung, Gambuh and Kinanti. (Any 1983: 3).

Serat Wedhatama is the work of the leader and poet of Mangkunegaran. This literary work is the most famous of his various works. The sentence structure is very interesting to hear, so it vibrates feelings and can be used as a means of training and building character / soul. This is a sign that Serat Wedhatama is the creation of the main human being guided by God. Kanjeng Gusti Pangeran duke Aryo Mangku Negaran to IV or Sri Mangkunegaran IV is the great-grandson of the late Sri Mangkunegaran I. He is the grandson of Sri Mangkunegaran II. Sri Mangkunegaran IV was born with the name Raden Mas Sudira, he was married to the daughter of Kanjeng Pangeran Suryomentaram and changed his name to Raden Mas Haryo Gondokusuman (Aryo Gondokusumo 1994: 7). In 1840 he was appointed as major who controlled the administration of Mangkunegaran leguins. On March 24, 1853, at the age of 43 he was appointed to replace Mangkunegaran III who died, and was given the title Kanjeng Gusti Pangeran Adipati Aryo Prabu Pragwandana. Sri Mangkunegaran died on Friday, September 8, 1881 at the age of 75, after having reigned for 25 years leaving 32 children. He is not a consort.

So that Wedhatama in his time was very famous, not only in the Mangkunegaran palace environment but also in the Kasunanan palace and the Yogyakarta Sultanate. Even Wedhatama is known and memorized to all corners of the village who speak Javanese, although only one and two stanzas but they are memorized by heart. Wedhatama is a philosophy or life guide.

\section{Wedhatama Fiber Content}

Wedhatama fiber consists of 100 stanzas which are included in five hundred (Dhanu, 2007: 246). The first pupuh is pangkuryang consisting of 14 stanzas, containing basic advice and teachings in dealing with life so that humans can live with a noble soul and knowledge. The second pupuh is Sinom which consists of 18 stanzas, the second stanza explains how to increase the dignity of life by achieving three things, namely living a noble life, looking for material things for life, looking for intelligence. The third pupuh is Pucung which consists of 15 stanzas, this pupuh explains that 
knowledge must be practiced, starting with the will, because the will is an amplifier that makes patience in the heart The fourth pupuh is Gambuh which consists of 35 stanzas explaining prayer chess, worshiping raga, worshiping the soul, and worshiping the taste. The fifth pupuh is Kinanthi consisting of 18 stanzas, this pupuh is additional verses in the Wedhatama Fiber, which aims to further clarify the meaning of the contents of this fiber, namely to carry out all the teachings in the Wedhatama Fiber one must be patient, tawakal, sincere, virtuous. have a mind or soul that is main / noble for every human being in the world (Aryo Gondokusumo 1994: 7).

Wedhatama fiber consists of 100 stanzas which are included in five stanzas: pangkur, sinom, pejung, gambuh and sinom. (Sabdacarakatama 2010: 7) The summary of the teachings in Wedhatama can be summarized into 2 groups:

a. Teachings for cadets (young people).

1) It is advisable to study dress and manners, as well as to understand the correct sources of knowledge.

2) Those who are arrogant or boastful (even if they have the knowledge of immunity) because this knowledge is actually not reliable, never be arrogant, even if the father is in power.

3) One should be able to carefully assess all kinds of teachings so that he will be able to place these teachings and choose which knowledge is in accordance with his own personal talents.

4) Be aware of what it means to fulfill darma, that is, while living in the world, it is mandatory for every human being to make an effort to achieve the trisarana of life, namely wisya, arta, wasis (knowledge, wealth, intelligence).

b. Teachings for the elderly

1) Knowledge or how to educate children.

2) How to determine or convince the truth of a science.

3) How do you perform prostration in the presence of Almighty God so that your efforts to face God are not in vain.

Even though a person is quite old (old), if they are not knowledgeable and do not understand ruas-rasa, they will definitely get the title tuwa-tuwas, it can be said that only because of their many ages. Parents like that can be likened to a sepah, after all his behavior is often embarrassing. (Sabdacarakatama 2010: 16-17). So Wedhatama means knowledge of goodness. But it is not only good knowledge about birth, but both in the physical and mental sense.

The wedhatama fiber is divided into 5 successive parts. Consists of Pangkur bait 1-14, Sinom bait 15-32, Pocung bait 33-47, Gambuh 48-82, Kinanthi bait 83-100 (Sabdacarakatama, 2010: 9). This research will examine the verses in the Wedhatama Fiber which are related to the research that the author did. Those are verse 1 , verse 3 , verse 4 , verse 5 , verse 8 , verse 10 , verse 11 , verse 13 , verse 14 , verse 15 , verse 16 , verse 17 , verse 24 , verse 31 , and verse 43 .

One of them is like Pangkur according to the tradition of speech, the pangkur meter was invented by Kanjeng Sunan Murya, for example the Pangkur verse: 
Mingkar mingkuring angkara,

Akarana karenan Mardi siwi,

Sinawung resmining kidung.

Sinuba sinukarta,

Mrih ketarta pakartining ngelmu luhung,

Kang tumrap ing tanah Jawa,

Agama ageming aji (Kamajaya, 1992 : 255)

Meaning

Abstain from lust

Because they want to educate children

In the form of beautiful poetry Decorated to make it look beautiful

In order to grow the soul and noble knowledge that applies in the land of Java

Religion is a good grip. (Anjar Any1983: 31)

There it is as if between angkara andakarana there is a fine thread connecting the two words so that they are easy to memorize. Likewise, the words siwi and sinawung, and so on. That is one of the reasons why the words in the Wedha Tama were very familiar to the people at that time. According to researchers, the ancient teachings in Serat Wedhatama which some people have considered are very relevant to be studied in today's modern life which is full of changes and progress that are very fast and radical, which here and there make many people forget their identity and identity. as a cultured human. Starting with this, the researcher tries to raise one of the Indonesian cultural heritages, namely Wedhatama, as one of the teachings that the values of moral education can explore in it.

Mothers in ancient times always sang the song Serat Wedha Tama when cradling babies or children who were still toddlers. They, including fathers, taught about virtue or the nature of virtue through the chanting of the verses contained in the Wedha Tama Fiber. Parents have the hope that their children will have good morals so that they can please others in their relationships. It is a fact that the generation who received the teachings of Serat Wedha Tama have a pleasant attitude, especially always upholding manners and respect for anyone.

Inside the Wedha Tama Fiber it is opened with pupuh Pangkur. Why is Wedha Tama opened with Pangkur? Pangkur is a beautiful and popular classic song, also the most popular song (tembang). It is hoped that the Pangkur song will be able to tie and open the door to the hearts of readers, composers or listeners of Wedha Tama to receive the essence of Wedha's teachings. Tama, namely the teachings of wisdom.

As the first song, Pangkur is a preface. With a loud and sharp tone that symbolizes sturdiness, this song warns people to stay away from the angry character of being angry with their own desires (mingkur - mingkur ing angkara, WT., Pp. 1), b-1). Serat Wedhatama emphatically explains that even though a person is old in age, if that person does not know "the knowledge of taste", then that person is like dregs (a piece of sugar cane) that has been sucked in as sweetness, or in other words, the person is lonely (without taste), empty, devoid of knowledge, so that even his behavior is awkward and embarrassing (gonyak - ganyuk nglilingsemi). 


\section{Relevance of Wedhatama Fiber with Islamic Education}

Education is life. Education is all learning practices that take place in all environments and throughout life. Education is all life situations that affect individual growth. (Maunah, 2009). The definition is also put forward by education experts that moral or character education is a process of transforming educational values to be grown and developed in a person's life so that they become one in the behavior of other people's lives. In this definition, there are three important thoughts, namely 1. The process of transforming values 2. Developing and developing in personality and 3. Becoming one in behavior (Machali, 2011: 7)

As is often emphasized in the Wedhatama fiber, namely "Sinawung Resmining Kidung" about pitutur or good and beautiful words that are able to touch the minds of those who listen to them. As is the case in the Javanese proverb Ajining self soko obahing lathi this expression is rarely heard, and many have forgotten. The meaning of this expression is that one's self-respect depends on what is said. The point is not just moving the lips, (obahing lathi) or just talking, but what is said through the lips needs to be considered carefully. Meaning: "And call (the name) of your Lord in your heart with humility and fear, and without raising your voice, in the morning and evening, and do not include you who are negligent." (Surah Al-a'raf 205). (Ministry of Religion of the Republic of Indonesia, AlQur'an and its translation 2013: 256).

Dzikir is a constant reminder of Allah in the heart and speaks his name orally. This dhikr is useful as a control tool for heart, speech and deeds so as not to deviate from the line set by Allah SWT (Nata 2017: 239). Since it was really not understanding if it didn't understand, he always felt that his opinion was the most correct of his own. Even if you speak it gets louder and louder regardless of other people's opinions and doesn't know the place, time, and atmosphere. He does not want to be said to be stupid, even though he is actually stupid, instead he always asks for praise (uger guru aleman, ugungan sadina - dina, WT, pp I.b-3).

The songs he composed are decorated with interesting words so that without feeling this noble teaching sink into the heart. Noble knowledge has the power to influence character formation in accordance with the psychological basics of the Javanese (Indonesian), so those who study it will undoubtedly be led to a good character (Divinity). In Serat Wedha Tama, there is a recommendation that people never stop absorbing the essence of the teachings of virtue. An elderly person, who is easily forgetful or easy to make mistakes, if he does not feel the true taste, he will still lack understanding and subtle feelings. Usually in good traditional poetry there is a mystery so it is rather difficult to say the meaning of the tembang. But it must be added immediately, the opposite statement applies. A song that is difficult to know the meaning is good traditional poetry, this is not true. Famous authors are always dissatisfied with language informative that is simply collected or combined. Therefore, it is quite useful to state it, even if it is only simple.

The theme described earlier is the main theme there are still additional themes that are considered important as well. Serat Wedha Tama is a work that has a lot of weight and contains quite deep meaning. The words arranged in each other are always connected and look beautiful and 
attractive. When compared to other works, the ties and strings of words are better, thematically the song does not repeat itself. Additional themes exposed in Wedha Tama Fiber include: (1) Teaching of inner and outer life, (2) Almighty Godhead, (3) Teaching of Wisdom and associating, (4) Respecting the views of others, (5) having a chivalrous spirit, (6) struggling for life, and (7) themes of worship religion well. The inner structure of the poetry expresses what the poet intends to convey with his feelings and mental atmosphere. There are four essential elements in the inner structure of the poem, namely: (1) the theme (sense), (2) the poet's feelings (feeling), (3) the poet's tone or attitude towards the reader (tone), and the intention (intention).

According to the author, The educational values conveyed in Wedha Tama still have relevance for use by the general public, education circles in schools today. These values are mainly related to the cognitive aspects of the domain or aspects of student values and attitudes. The attitude of throwing away all passion evil, uncontrollable emotions, selfish, lazy and so on. The attitude of wanting to build enthusiasm for work or enthusiasm for studying actively, spurring achievement for a decent and physically peaceful life. The attitude of wanting to establish good relationships with others, so as to foster an atmosphere of tolerance, an atmosphere of kinship and togetherness. As for the affective aspect of the domain or aspects of science and knowledge, the convention itself is capable of giving an inner touch that improves human morals.

As the concept of Western education, Islamic education is education that is aware of the goals, even Islamic education has the most prominent objective characteristics, namely its religious and moral characteristics. The overall character which includes all aspects of the student's personality and all aspects of development in society. The objectives are clear and balanced, there is no conflict between the elements and the ways of implementation. (al-Syaibany, 1979: 436). Akhlak or Khuluq is a trait that is embedded in the human soul, so that it will appear spontaneously when needed, without the need for prior thought or consideration, and does not require external encouragement (Ilyas 1999: 2)

The word morality comes from Arabic which is the plural form of khuluq or khuluq, which means character, habit, religion, chivalry (Ariyanto, 1994: 86). In the National Action Plan for Moral Education (2010), it is stated that moral education is "education", character education, moral education and character education which aims to develop the ability of students to make good decisions, maintain what is good and realize that good in life. everyday with all my heart (Syarbini, 2012: 16).

Islamic education is very important for human development because with Islamic education human life becomes better and more prosperous, which can create an educated human, namely a complete human being insan kamil (Syarbini, 2012: 16). A person's Islamic education can be influenced by the environment, habits and what he learns. Reading sources such as books, literary works or books that have been studied also affect a person's behavior or morals, especially if the content of the reading source is very interesting, has values that can be applied in everyday life. 


\section{First and Last Wedhatama Pupuh Fiber Construction}

Serat Wulang, which contains piwulang (teaching) as the life of satra in the Surakarta palace in the 18th and 19th centuries, took place with the conversion of ancient Javanese literary works into the new Javanese language with tembang macapat. The rearrangement of ancient Javanese literature was intended, among other things, to rebuild the beauty of old literature into new Javanese literature, to keep glorifying literary works that were praised and noble and to elaborate teachings about the main insane that the general public deserves to know and some are based on the intention to re-express old traditions and want to reclaim ancient traditions.

Besides that, poets and literary writers tried to renew ancient traditions so that the wider community could re-live them (Amir Rochkyatmo Selatan 2002: 3). In order to understand the full meaning of Wedhatama, it is necessary to begin by knowing the outline of the contents of the stanzas on these fibers: 1). Pupuh tembang pangkur, is the opening of the teachings which in outline: (a) to walk towards "Penembah" must begin with "ngungkuraken angkara", which is to throw away the traits and attitudes of arrogance, greedy, greed, wrath, cunning, envy, envy etc; (b) the journey is carried out continuously until it manages to enter a truly limited state of arrogance and is in a realm filled with "silence" (lonely, suwung) which is marked by "liyep-layap-luyup". Imam Ghazali Glass

At the opening of the Wedhatama fiber, there has been a strong statement regarding the "angkara"? Angkara is the act and attitude of the soul that refers to self-interest, is bodily (physical, physical), low and temporary. Most people call Angkara including the class of lust. Basically the attitude of arrogance and lust is one part of human character, the expression of which is different, depending on the level of maturity of each soul (maturity of taste). For a person who is mature, his soul (natural maturity) will be able to control himself and be able to regulate the appearance of the impulses of lust in a subtle way so that in effect it does not show signs of being ruled by lust.

According to Wedhatama Fiber, humans as a good human being must fulfill several things, namely:
a. Attitude to hold back lust
b. Humility, not always winning alone
c. The attitude of being quiet, self-indulgent, busy, beguiling, swinging Bawana.
d. Attitude to hold back lust

Lust is a gross feeling, because it frustrates human self-control and blinds it to the outer realm. In Javanese view, lust is also dangerous, because humans are controlled by it and no longer indulge in their minds. Humans who indulge their lusts no longer develop their subtle aspects , increasingly threatening the environment and causing conflicts and tensions, to endanger peace. Allowing rampant lust according to Serat Wedhatama destroys the three realms in humans and causes many difficulties (Aryo Gondokusumo, 1994: 34).

To control lust, according to Serat Wedhatama, it is necessary to instruct or study with a mystic, abstain from arrogant lust or control that desire so that it is not controlled by it. According to 
Wedhatama, the person who is capable of doing this is Panmbahan Senopati from Mataram. Senopati's main attitude of practice needs to be emulated, because this senopati is trying day and night to extinguish the fluctuation of lust and thereby build the character of mutual love.

The problem of lust is always discussed in the Kejawen environment, for example by R.Ng. Ronggowarsito. In the Wedharaga Fiber and also in Paku Buwono IV in the fiber of "Wulang Reh", it is said that lust must be restrained, so that people can achieve their high aspirations. This is expressed as follows (Aryo Gondokusumo, 1994: 34). Wedhatama also touched on this by saying that all of this must be carried out in a healthy and reasonable manner. This path contains the qualities of piety, patience and willingness (Aryo Gondokusumo, 1994: 34). Serat Wedhatama begins with a teaching about divinity that has been embraced by the kings and by the Javanese aristocrats. This teaching is revealed in a luhung science which means main knowledge. Luhung science has been considered the state religion for a long time (Aryo Gondokusumo, 1994: 34).

Ngelmu luhung or main knowledge is based on the Javanese view of "sangkan paraning dumadi" and the mystical "manunggaling kawulo gusti". The basis of thinking is as follows: humans perceive the world and thus the world exists in human consciousness. On the contrary, the world is a place of birth, life, work and death. In other words, humans exist in the world. Therefore, it can be concluded that humans and the world are unity, because they complement each other. This is a paradox that in Serat Wedhatama is said to be a large universe and a small universe that complement each other (Aryo Gondokusumo, 1994: 34).

Every adult human being, both male and female, in order to obtain the salvation of glory and glory in carrying out his worldly life duties, thus the fourth mangkunegaran, he must carry out the principles of good life behavior. Such behavior, not only enables a person to gain the glory and respect of others, but also enables him to gain salvation in this world and in the hereafter. This worldly life ethic is praiseworthy behavior which includes: obedience to religion (in this case Islam), courtesy in social relationships, actively working to earn a living, diligently studying knowledge to control lust and having high aspirations.

The behavior of this world life, although in a limited scope according to the fourth mangkunegaran is considered sufficient if it is appointed as a practical life guide, especially for the Javanese people. These guidelines, as mentioned earlier in many piwulang, Darmalaksita, and Wedhatama fibers . As only in other fibers, Mangkunegaran has its own way of teaching lessons. He gave information and examples between good and evil, then he contrasted them sharply so that they were easy to understand and understand.

In general, following religious instructions in worldly life which is associated with the application of character, needs to be taught and accustomed to students from childhood. The material for education on religion and character needs to be composed as beautifully as possible and taught in a gentle and gentle way, so that it will attract more students' interest. Religion, which became one of the king's holdings, which taught character and character which had become popular in the community and was rooted in the traditions of the Javanese people, they would be more interested in and loved more if it was conveyed in good and attractive ways. Conversely, if religion, even though it contains good teachings, is conveyed in a harsh way, it does not make people closer to religion, but 
further away from religion. Therefore, religion which contains the teachings of virtue, needs to be taught in a wise, gentle and attractive way, as expressed by the fourth mangkunegaran in wedhatama fibers.

Character or virtue, as one of the basic teachings in religion, in order to be implemented in society, it is necessary to support the king and all his apparatus. Meanwhile, a king who is aware of his mission and duty to uphold goodness, must need religious guidance, as seen in the expression "religion ageme aji". Religion here is in accordance with its meaning which includes aspects of faith, worship and morals that have been incarnated in the traditions of daily life, by the king making them his clothing for his life, both for himself and for his people, said Mangkunegaran IV regarding the position of religion.

He not only uses this meaningful religion, he loves and he obeys, but also has a personality that deserves to be emulated and adhered to by all his people. In this way, educated students will be created, the next generation who are virtuous, at least for the land of Java, that is what mangkunegaran IV wants. In obeying religion, he emphasized that a person should imitate what was exemplified by the apostle guiding people around the world (Prophet Muhammad PBUH), but not to show off, to be proud and not to be a means of seeking rank, by exemplifying the craft of coming to mosques etc.

\section{Conclusions}

The Indonesian nation is a large nation with its multiculturalism giving a rich color to its cultural heritage, which is stored in regional culture throughout the archipelago, which is spread from Sabang to Merahoke. Cultural heritage is in the form of written and unwritten relics, such as petilasan, temples, and literary works of both fiction and non-fiction, all of which are very valuable cultural values possessed by the Indonesian people.

Among the areas that are rich in culture and literature are the Javanese. In Java we find many written remains, in the form of texts containing Moral education (Akhlak), religious teachings, philosophy, and kasampurnan sciences. So in Javanese literature we recognize the existence of suluk books, Wirid, Primbon, Menak, babad and others.

In Serat Wedha Tama, there is a recommendation that people never stop absorbing the essence of the teachings of virtue. An elderly person, who is easily forgetful or easy to make mistakes, if he does not feel the true taste, he will still lack understanding and subtle feelings. Usually in good traditional poetry there is a mystery so it is rather difficult to say the meaning of the tembang. But it must be added immediately, the opposite statement applies. A song that is difficult to know the meaning is good traditional poetry, this is not true. Famous authors are always dissatisfied with language informative which is simply collected or combined. Therefore it is quite useful to put forward, even if it's only simple. In taking the aspect of place based on the formal aspect, then it will be known. 


\section{References}

al-Syaibany, Omar Muhammad al-Toumy. (1979). Philosophy of Islamic Education (trans. Hasan Langgulung). Jakarta: Bulan Bintang,

Any, Anjar. 1983. Revealing Wedotomo Fibers. Semarang: Various Sciences.

Ariyanto, M. Darojat. (1994). Study Islam 1. Surakarta: LPID UMS.

Damana, Sapardi Djaka. (1978). Sociology as a Brief Introduction. Jakarta: Kemendikbud.

Darusuprapta. (1986). Moral Teaching in Suluk Literature. Yogyakarta: UGM Press.

Gondokusumo, Aryo. 1994. Serat Wedhatama. Semarang: Dahara Prize.

Ilyas, Yunahar. (1999). Lecture of Morals. Bantul: LPPI: Bantul.

Kamajaya. (1992). Choice of Member of KGPAA Mangkunegaran IV. Yogyakarta: Yayasan Centhini.

KGPAA Mangkunegara IV. (1989). Serat Wedhatama. Semarang: Dahara Prize.

Koentjaraningrat. (1985). Javanese Culture. Yogyakarta: Balai Pustaka.

Machali, Imam. (2011). Mujahid Character Education. Yogyakarta: Aura Pustaka.

Maunah, Binti. (2009). Educational Foundation. Yogyakarta: Teras.

Ministry of Religion of the Republic of Indonesia. (2013). Al-Qur'an and its translation, (Jakarta: PT. Insan Media Pustaka.

Nata, Abudin. (2000). Methodology of Islamic Studies. Jakarta: Raja Grafindo Persada.

Nata Abudin. (2017). Sufism Morals and Noble Characters. Depok: Raja Grafindo Persada.

Simuh. (1986). Mystical Value in Javanese Culture and Literature. Yogyakarta: Indonesian Language Research Institute.

Subagyo. (1991). Research Methodology in Theory and Practice. Jakarta: Rineka Cipta.

Syarbini, Amirullah. (2012). Smart Book of Character Education. Prima Pustaka: Yogyakarta.

Usman, Husaini and Purnomo Setiadi Akbar. (1996). Social Research Methodology. Jakarta: Bumi Aksara.

Wibawa, Sutrisna. (2013). Javanese Philosophy in Wedhatama Fiber. IKADBUDI, Volume 2 December 2013. 